\title{
DISTRIBUTION OF INDIGENOUS AND NON-INDIGENOUS CRAYFISH POPULATIONS IN THE POITOU-CHARENTES REGION (FRANCE): EVOLUTION OVER THE PAST 25 YEARS
}

\author{
M. BRAMARD (1), A. DEMERS (2), M.-C. TROUILHE (2), E. BACHELIER (3), \\ J.-C. DUMAS (3), C. FOURNIER (3), E. BROUSSARD (3), O. ROBIN (3), \\ C. SOUTY-GROSSET (2) and F. GRANDJEAN (2)
}

(1) Délégation Régionale du Conseil Supérieur de la Pêche, 112 Faubourg de la Cueille, 86000 Poitiers, France.

(2) Laboratoire de Génétique et Biologie des Populations de Crustacés, UMR CNRS 6556, Université de Poitiers, 42, avenue du recteur Pineau, 86022 Poitiers cedex, France.

(3) Brigades départementales du Conseil Supérieur de la Pêche de Charente, CharenteMaritime, Deux-Sèvres et Vienne, France.

Corresponding author: frederic.grandjean@univ-poitiers.fr

Reçu le 23 juin 2005

Accepté le 21 novembre 2005

Received June 23, 2005

Accepted November 21, 2005

\begin{abstract}
Subsequent surveys carried out from 1978 to 2003 demonstrated a high disappearance of Austropotamobius pallipes populations from the region and the alarming spread of non-indigenous species like Procambarus clarkii and Pacifastacus leniusculus. Represented by 137 populations in 1978, A. pallipes is now almost completely restricted to only one department, with 45 populations recorded, representing a decrease of $68 \%$ of the population number in 25 years, with a loss of $40 \%$ of populations in the last 6 years. Most of the disappearances of crayfish are unexplained. For the 22 others, the main reasons of the disappearance of indigenous crayfish populations were due to (1) habitat destruction by channelisation, (2) decrease of water quality by use of agricultural chemicals, (3) the construction of ponds or lakes changing the physical and chemical parameters of brooks inhabited by indigenous crayfish, (4) the introduction of non-indigenous species, mainly $P$. leniusculus and recently (5) crayfish plague implicated and characterized in the disappearance of two populations, two additional ones being suspected.
\end{abstract}

Introduced in 1978 in Vienne department, $P$. leniusculus has now been found in 28 locations. First record of $P$. clarkii was in 1988 in Charente-Maritime department; since it has spread in most of the hydrographic basin of this department.

Key-words: Austropotamobius pallipes, Non-indigenous crayfish, Distribution, Poitou-Charentes, France. 


\section{RÉPARTITION DES POPULATIONS D'ÉCREVISSES INDIGÈNES ET NON INDIGÈNES DANS LA RÉGION POITOU-CHARENTES (FRANCE) : ÉVOLUTION SUR 25 ANS}

\section{RÉSUMÉ}

D'importants suivis de population d'écrevisses effectués entre 1978 et 2003 ont montré une forte disparition des populations d'A. pallipes et une propagation alarmante des espèces non indigènes comme $P$. clarkii et $P$. leniusculus. Représentées en 1978 par 137 populations, le nombre est à présent de 45 populations, représentant une diminution de $68 \%$ en 25 ans, avec une perte de $40 \%$ des populations ces cinq dernières années. La plupart des disparitions de populations sont inexpliquées. Pour les disparitions dont les causes peuvent être présumées ou observées, on trouve par ordre décroissant d'importance: (1) la destruction de l'habitat (recalibrage), (2) la diminution de la qualité de l'eau par utilisation de produits chimiques pour l'agriculture, (3) la construction de mares ou d'étangs qui changent les paramètres physico-chimiques des cours d'eau (4) l'introduction d'écrevisses non indigènes, principalement $P$. leniusculus et récemment (5) la peste de l'écrevisse qui a été caractérisée dans la disparition de 2 populations, et suspectée dans 2 autres cas.

Introduite en 1978 dans le département de la Vienne, P. leniusculus est présente dans 28 sites (de ce département). Les premières observations de $P$. clarkii datent de 1988 en Charente-Maritime, depuis elle s'est étendue à la plupart des bassins hydrographiques de ce département.

Mots-clés: Austropotamobius pallipes, écrevisses non indigènes, répartition, Poitou-Charentes, France.

\section{INTRODUCTION}

The white-clawed crayfish, Austropotamobius pallipes (Lereboullet) is an indigenous crayfish species found in Western Europe (geographic distribution reviewed in HOLDICH, 2002). Its distribution is now greatly reduced throughout its natural range due to several causes: (i) the pollution of freshwaters by domestic, agricultural, or industrial wastes, which can be totally toxic and responsible for major declines in the populations, (ii) habitat loss with engineering works, which can completely destroy the habitat of freshwater species; (iii) overfishing/overexploitation; (iv) introduction of alien species highly tolerant to the crayfish plague and acting as vectors of this disease; this fungus has killed off most populations of the white-clawed crayfish in Spain following the introduction of Procambarus clarkii (ALONSO et al., 2000).

As a result of this decline, this species is included in Appendix III of the Bern Convention as protected species and in the Red Data List of endangered species by the International Union for the Conservation of Nature and Natural Resources (GROOMBRIDGE, 1993). In response to the Convention on Biological Diversity signed at the Earth Summit in Rio de Janeiro in 1992, the species was also included in Annex II and $V$ of the Habitat Directive 92/43/CEE of the European Community. This species is also regarded as a heritage species (FÜREDER and REYNOLDS, 2003). Furthermore, in habitats where it occurs, A. pallipes is considered as a keystone species (MATTHEWS et al., 1993; NYSTRÖM, 2002).

In France, the species occupies mainly streams. It prefers calcium-rich rivers and streams with a good water quality and not too much sediment. Shelter such as that provided by rocks/stones, water plants and tree roots, or a bank into which it can burrow, are important for its survival. It is now mostly found in the headwaters of rivers, in isolated populations. 
Three non-indigenous species originating from the North American continent were represented in the French hydrographic system. Amongst them, Orconectes limosus is the most widely spread. Since its introduction between 1911-1913 with 2000 individuals, it has occurred in all French drainages mainly within large rivers, from second order (small rivers) and up (VIGNEUX, 1997; ARRIGNON et al., 1999). The signal crayfish (Pacifastacus leniusculus) occurred in 1995 in 47 departments since its introduction from Sweden in 1972 and from the USA in 1974 (LAURENT, 1997). This species is a direct competitor of the indigenous $A$. pallipes because it shares the same habitat in headwaters of rivers. The Louisiana crayfish (Procambarus clarkii) was introduced in 1974 into Western France and by 1995 it had reached 36 departments, particularly marshy and rice area in Brittany and the Camargue (ROSECCHI et al., 1997).

The present paper describes the evolution of indigenous and alien populations of crayfish within a French region since 1977 from historical data of national fisheries French council and field operations performed in summer 2003. When a population of $A$. pallipes could not be found again, the causes for this disappearance were investigated. These causes were extremely poorly known in the literature. This detailed mapping is a prerequisite for a conservation plan.

\section{METHOD}

The region of Poitou-Charentes covers $25810 \mathrm{~km}^{2}$ in Western France and possesses mostly calcareous soils offering a favourable hydro-chemical profile for crayfish. It has four Départements: Vienne, Deux-Sèvres, Charente and Charente-Maritime (Figure 1).

\section{Figure 1}

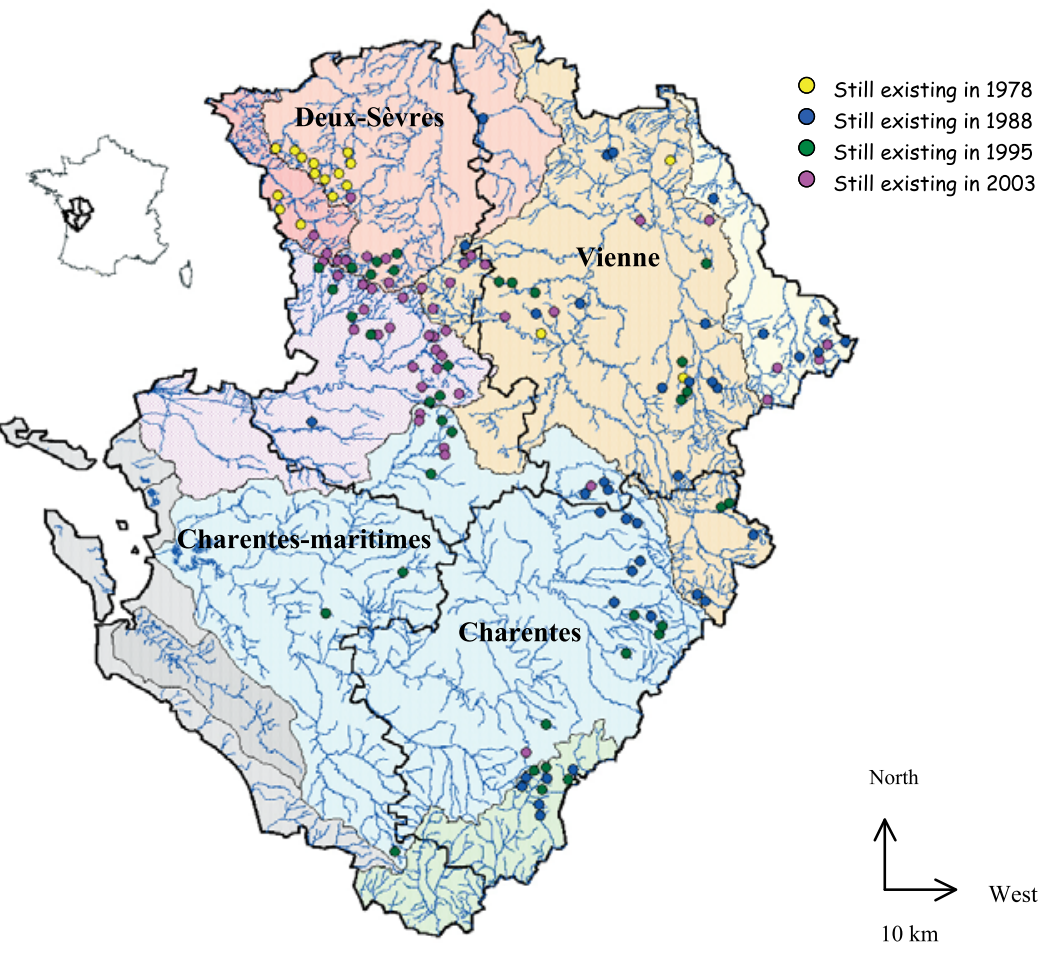

Distribution of $A$. pallipes populations since 1978 with hydrographic network (blue lines) and departement limits (black lines).

Figure 1

Distribution des populations d'A. pallipes depuis 1978 avec le réseau hydrographique (lignes bleues) et les limites départementales (lignes noires). 
This paper presents data collected both by the Brigades Départementales of Conseil Supérieur de la Pêche (CSP) from four major crayfish surveys carried out in 1978, 1988, 1995 and 2002 (VIGNEUX et al., 1993; CHANGEUX, 1996; VIGNEUX, 1997; CHANGEUX, 2003 ) and by complementary surveys (on 20 sites), done in 2003, mainly in the Vienne and Deux-Sèvres departments. Crayfish were sampled using baited traps in deep waters or captured by hand where the water level was shallow enough. In 2003, 10 traps spaced at $10 \mathrm{~m}$ intervals were used. The traps are long and conical; the greatest diameter is $240 \mathrm{~mm}$ and the smallest $150 \mathrm{~mm}$. The traps are injection moulded in blue polyethylene plastic with mesh size of $14 \mathrm{~mm}$. Traps baited and set in the afternoon were retrieved the following morning after 12 hours.

These surveys only recorded presence or absence of crayfish at sites where $A$. pallipes was expected to occur. To confirm the disappearance of an A. pallipes population, field operation with lights by night was also performed. When a population of $A$. pallipes could not be found again, the causes for this disappearance were investigated.

\section{RESULTS}

\section{A. pallipes}

Crayfish used to be widely distributed in the Deux-Sèvres and were well represented throughout the Vienne and Charente départements (Figure 1). In 2003, they were mostly found in the Deux-Sèvres département, with only a few isolated populations in the other parts of the Poitou-charentes region. In 1978, 137 populations of $A$. pallipes were recorded in the region. In 1988, 120 populations were found and by 1995 only 81 populations existed in the region, a loss of more than $30 \%$ of crayfish populations in just 7 years. In 2003 , only 45 populations were recorded, representing only $32 \%$ of the 1978 number.

Most of the disappearances of crayfish are unexplained. The main known causes for the loss of crayfish populations in the region are the crayfish plague (Aphanomyces astaci), the introduction of non-indigenous species, habitat degradation and pollution (Table I). Pesticides were implicated in the loss of few populations, including one in the Crochet stream (Vienne), where the chemicals lambda cyanalochtrine and isoproturon were identified. Organic pollution (farm waste) was also found to be the cause for the loss of at least two populations. At least, two populations in the Deux-Sèvres department disappeared following the creation or the maintenance of a pond. The occurrence of crayfish plague, $A$. astaci, was confirmed in the St-Christophe river from Deux-Sèvres (NEVEU and BACHELIER, 2002) and suspected in 3 other rivers in 2001. Drought can also cause the loss of a population. During summer 2003, an unprecedented heat wave hit France and two crayfish sites in the Vonne catchment (Poitou-Charentes) completely dried out.

\section{Table I}

Known causes for disappearance of $A$. pallipes.

\section{Tableau I}

Causes connues de la disparition d'A. pallipes.

\begin{tabular}{lc}
\hline Cause & Number of populations affected \\
\hline Pollution (organic) & 4 \\
Pollution (toxic) & 8 \\
Creation or maintenance of a pond & 4 \\
Aphanomycoses & 4 \\
Drought & 2 \\
Exotic crayfish & 4 \\
\hline
\end{tabular}




\section{Non-indigenous crayfish}

The introduction of non-indigenous crayfish, mainly $P$. leniusculus, is also implicated in the loss of indigenous populations. Orconectes limosus has been widely distributed in the main rivers of the region for almost a century (ARRIGNON, 1997), but $P$. clarkii and $P$. leniusculus are relative newcomers, being first sighted in the surveys of 1988 and 1978 respectively. These two species have spread considerably in diffusive way since their introduction, $P$. clarkii in the Charente-Maritime department and P. leniusculus in the Vienne department (Figure 2). There are now 28 populations of $P$. leniusculus recorded in the Vienne department. They are situated in the headwaters of rivers and result from both human translocations and natural colonisation. One example of cohabitation between $O$. limosus (dam brook) and $A$. pallipes occurs in the Rourie brook.

One population of Astacus leptodactylus has been recorded in Auxances brook (Deux-Sèvres department).

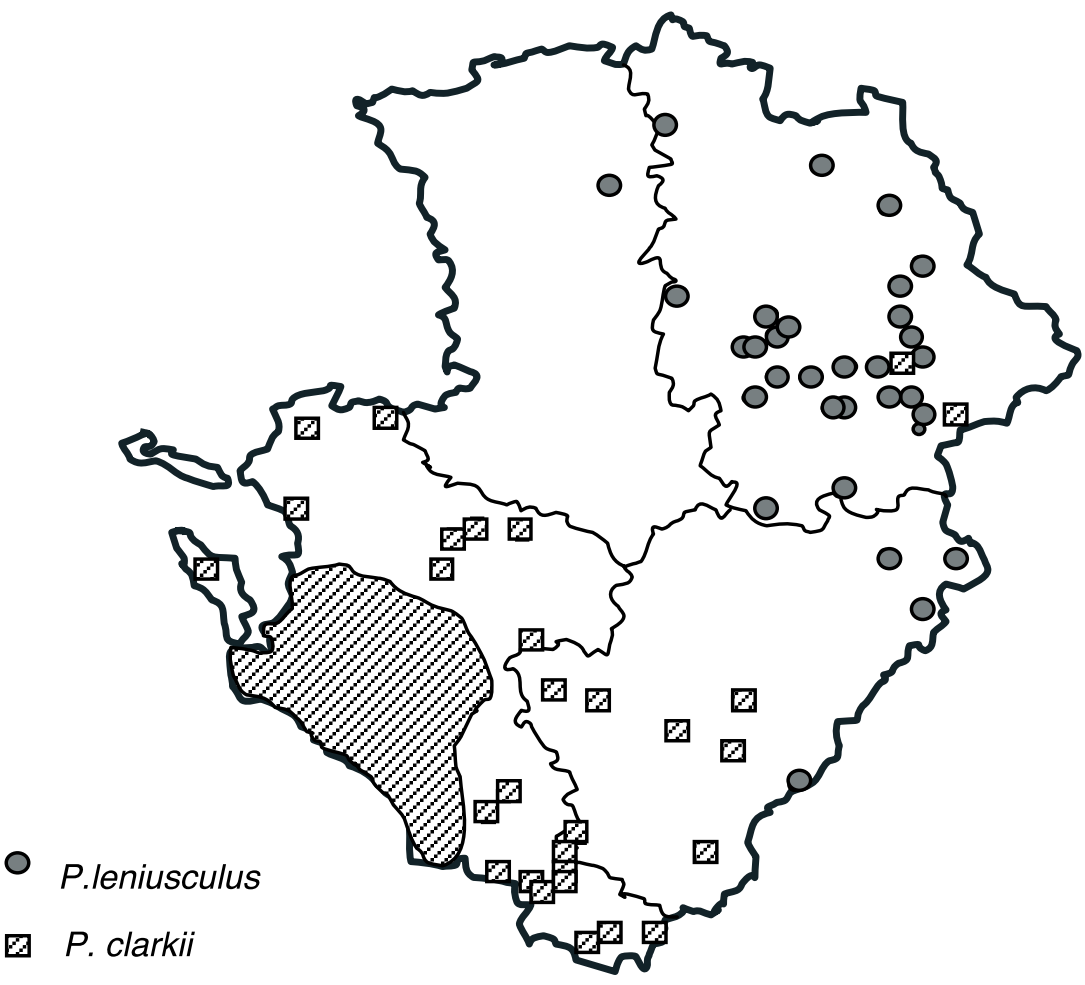

North

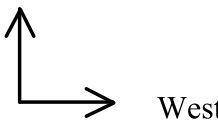

$10 \mathrm{~km}$

Figure 2

Distribution of $P$. clarkii (hatched squares) and $P$. leniusculus (grey circles) in Poitou-Charentes region. The shaded area represents a zone where $P$. clarkii is widely distributed. First records for $P$. clarkii in 1988 and for $P$. leniusculus in 1978 in Vienne.

Figure 2

Distribution de $P$. clarkii et $P$. leniusculus dans la région Poitou-Charentes. Les aires hachurées représentent une zone colonisée par $P$. clarkii. Premiers signalements de $P$. clarkii en 1988 dans la zone hachurée et de $P$. leniusculus en 1978 en Vienne. 


\section{DISCUSSION}

The surveys carried out over the past 25 years demonstrate the loss of many indigenous crayfish populations in the Poitou-Charentes region. Only about a third of the populations remain today in this part of France. This situation is unfortunately similar to that in other regions of France (for example, the department of Creuse) and elsewhere in Europe (GHERARDI and HOLDICH, 1999; CHANGEUX and LAURENT, 2003; CHANGEUX, 2003). The many causes of this decline include the crayfish plague, pollution, habitat alterations and the introduction of non-indigenous species.

Crayfish plague was first reported in Europe in the $19^{\text {th }}$ century with massive mortalities observed in Italy, France and Germany (reviewed in ALDERMAN, 1996). This disease has affected indigenous crayfish stocks throughout the European continent, most recently in Britain (ALDERMAN et al., 1984), Ireland (REYNOLDS, 1988) and Spain (ALONSO et al., 2000). Although widespread mortalities in France caused by $A$. astaci mostly occurred from 1876 to 1884 (ALDERMAN, 1996), this disease still constitute today a threat to the conservation of $A$. pallipes. Several plague events have been recorded in recent times, in various regions (MACHINO and DIEGUEZ-URIBEONDO, 1998; COLLAS and SALEK, 2002). In England, after a lull of several years, one case of plague was reported in Cambridgeshire in 1999 (SLATER et al., 2000; HOLDICH, 2003). As long as resident populations of American crayfish, which are tolerant vectors of the fungus, exist In France, the threat of contamination to indigenous crayfish remains important. The spores of $A$. astaci can be transported from one river to another through fish introductions or possibly through fishing gears (REYNOLDS, 1988; OIDTMANN et al., 2002).

Pollution, particularly from pesticides, was implicated in the loss of several populations in Poitou-Charentes. Pollution events might be the cause of many population losses in Europe, but this is often difficult to ascertain. Indeed, contamination by pesticides is often brief and the presence of molecules can break down quickly. Is it therefore difficult to confirm that pesticides are responsible for the disappearance of a crayfish population. Contamination by sheep dip was believed to have a cause on the decline of $A$. pallipes in Wales (HOWELLS and SLATER, 2003). Synthetic pyrethroids (such as lambda cyanlochtrine, identified in Poitou-Charentes), used for sheep dipping, are particularly toxic to invertebrates and thus, freshwater crayfish (HOWELLS and SLATER, 2003).

Habitat degradation due to drought or anthropogenic modifications is also cited as a cause of the decline of $A$. pallipes in Europe. Human disturbances that affect crayfish include canalisation, dredging, construction of reservoirs and engineering works (MCCARTHY, 1977; GHERARDI et al., 1999; GUTIÉRREZ-YURRITA et al., 1999). Crayfish populations in France are susceptible to drought because they inhabit headwater sites, where the river is narrow and shallow. Drought has also been found to be problematic in Portugal and Italy (MORI et al., 1996; GHERARDI et al., 1999; GUTIÉRREZ-YURRITA et al., 1999). Artificial private ponds, constructed for fishing or as water reserves, are of common occurrence in the Poitou-Charentes region. The creation of a pond can be detrimental to a downstream crayfish population because of the resulting modifications in flow, dissolved oxygen, temperature or sedimentation. These ponds are sometimes emptied into the river, which loads the water flow with sediments, organic matter and result in poorly oxygenated water.

Non-indigenous crayfish species were introduced for their fisheries and aquaculture potentiel. Pacifastacus leniusculus was stocked in European rivers as a replacement for the indigenous populations devastated by plague. It was first sighted in Poitou-Charentes in 1978. The signal crayfish comes into direct competition with A. pallipes because it prefers first order streams in the headwaters of catchments, and occupies similar habitats (HILEY, 2003; CHANGEUX, 2003). Pacifastacus leniusculus is a vector of the crayfish plague, but even when plague-free populations of signal crayfish coexist with $A$. pallipes, the former will eventually outcompete the later (HOLDICH and DOMANIEWSKI, 1995; 
HOLDICH et al., 1995). Procambarus clarkii tends not to inhabit the same habitat as $A$. pallipes, preferring the marshes of Charente-Maritime. In Spain and Italy, this invasive species can be found in high densities in rice fields, marshes and ponds (GHERARDI et al., 1999; GUTIÉRREZ-YURRITA et al., 1999).

Finally, the sunfish, Lepomis gibbosus are responsible to extinction of white-clawed crayfish in one of the seven ponds in the natural reserve of Pinail (Vienne department).

\section{CONCLUSIONS}

The indigenous crayfish $A$. pallipes is now restricted mostly to two departments in the region (Deux-Sèvres and Vienne). In 2004, no population of $A$. pallipes has been found in two other departments (Charente and Charente-Maritime) (Bramard, Pers. Com.).

Non-indigenous crayfish species on the other hand are expanding their distribution and increasing in numbers. The surveys carried out over the past 25 years underline the need for strict conservation measures to preserve the remaining white-clawed crayfish populations in the Poitou-Charentes region. Despite national legislation, which prevents the importation of non-indigenous living crayfish from foreign countries and transport of live animals through the country, the spreading of non-indigenous species is impressive and very worrying for the future of $A$. pallipes in our region. Methods to eradicate localized populations should be attempted (review by SOUTY-GROSSET et al., 2004). For the others that cannot be eradicated, measures allowing controlling the spread of non-indigenous crayfishes should be taken.

\section{ACKNOWLEDGEMENTS}

Thanks to the persons of the four Brigades départementales of the Conseil Supérieur de la pêche in the Poitou-Charentes region for having given us the historical data and for their participation in the inventory.

\section{REFERENCES}

ALDERMAN D.J., 1996. Geographical spread of bacterial and fungal diseases of crustaceans. Revue scientifique et technique de l'Office international des épizooties, 15(2), 603-632.

ALDERMAN D.J., POLGLASE J.L., FRAYLING M., HOGGER J., 1984. Crayfish plague in Britain. Journal of Fisheries and Diseases, 7, 401-405.

ALONSO F., TEMIÑO C., DIÉGUEZ-URIBEONDO J., 2000. Status of the white-clawed crayfish, Austropotamobius pallipes (Lereboullet, 1858), in Spain: distribution and legislation. Bull. Fr. Pêche Piscic., 356, 31-54.

ARRIGNON J.C.V., 1997. Status of foreign crayfish in France. Freshwater Crayfish, 11, 665-670.

ARRIGNON J.C.V., GÉRARD P., KRIER A., LAURENT P.J., 1999. The situation in Belgium, France, and Luxembourg. In: F. GHERARDI and D.M. HOLDICH (Eds), Crayfish in Europe as alien species: How to make the best of a bad situation? A.A. Balkema. Rotterdam. pp. 129-140.

CHANGEUX T., 1996. Premiers résultats de l'enquête express écrevisses. Conseil Supérieur de la Pêche, Circulaire D003 du 15/10/95, 5 p.

CHANGEUX T., 2003. Changes in crayfish distribution in metropolitan France according to the national surveys performed by the Conseil Supérieur de la Pêche from 1977 to 2001. Bull. Fr. Pêche Piscic., 370-371, 17-41. 
CHANGEUX T., LAURENT P.J., 2003. Répartition et évolution des populations d'écrevisses en France telle que le font apparaître les résultats de l'enquête menée par le CSP (Conseil Supérieur de la Pêche) en 2001. L'Astaciculteur de France, 76, 5-14.

COLLAS M., SALEK X., 2002. Description d'un cas de peste de l'écrevisse ou aphanomycose dans le département des Vosges. L'Astaciculteur de France, 70, 2-6.

FÜREDER L., REYNOLDS J.D., 2003. Is Austropotamobius pallipes a good bioindicator? Bull. Fr. Pêche Piscic., 370-371, 157-163.

GHERARDI F., BALDACCINI G.N., ERCOLINI P., BARBARESI S., DE LUISE G., MAZZONI D., MORI M., 1999. The situation in Italy. In: F. GHERARDI and D.M. HOLDICH, (Eds). Crayfish in Europe as alien species. How to make the best of a bad situation? A.A. Balkema. Rotterdam. pp. 107-128.

GHERARDI F., HOLDICH D.M. (Eds).1999. Crayfish in Europe as alien species. How to make the best of a bad situation? A.A. Balkema. Rotterdam. 299 p.

GROOMBRIDGE B., 1993. IUCN Red list of threatened animals. IUCN, Gland Switzerland and cambrigde, UK, $286 \mathrm{p}$.

GUTIÉRREZ-YURRITA P.J., MARTÍNEZ J.M., BRAVO-UTRERA M.Á., MONTES C., ILHÉU M., BERNARDO J.M., 1999. The status of crayfish populations in Spain and Portugal. In: F. GHERARDI and D.M. HOLDICH, (Eds). Crayfish in Europe as alien species: how to make the best of a bad situation? A.A. Balkema. Rotterdam. pp. 161-192.

HILEY P.D., 2003. The slow quiet invasion of signal crayfish (Pacifastacus leniusculus) in England - Prospects for the white-clawed crayfish (Austropotamobius pallipes). In: D.M. HOLDICH and P.J. SIBLEY (Eds). Management and Conservation of Crayfish. Proceedings of a conference held on $7^{\text {th }}$ November, 2002. Environment Agency. Bristol. pp. 127-138.

HOLDICH D.M., 2002. Distribution of crayfish in Europe and some adjoining countries. Bull. Fr. Pêche Piscic., 367(4), 611-650.

HOLDICH D.M., 2003. Crayfish in Europe - An overview of taxonomy, legislation, distribution, and crayfish plague outbreaks. In: D.M. HOLDICH and P.J. SIBLEY (Eds). Management and Conservation of Crayfish. Proceedings of a conference held on $7^{\text {th }}$ November, 2002. Environment Agency. Bristol. pp. 15-34.

HOLDICH D.M., DOMANIEWSKI J.C.J., 1995. Studies on a mixed population of the crayfish Austropotamobius pallipes and Pacifastacus leniusculus in England. Freshwater Crayfish, 10, 37-45.

HOLDICH D.M., READER J.P., ROGERS W.D., HARLIOGLU M., 1995. Interactions between three species of crayfish (Austropotamobius pallipes, Astacus leptodactylus and Pacifastacus leniusculus). Freshwater Crayfish, 10, 46-56.

HOWELLS M., SLATER F., 2003. Return of the native crayfish to a Welsh river. In: D.M. HOLDICH and P.J. SIBLEY (Eds). Management and Conservation of Crayfish. Proceedings of a conference held on $7^{\text {th }}$ November, 2002. Environment Agency. Bristol. pp. 104-111.

LAURENT P.J. 1997. Crayfish introductions into France and in the world, history and consequences. Bull. Fr. Pêche Piscic., 344-345 (611-65, 2), 345-356.

MACHINO Y., DIEGUEZ-URIBEONDO J., 1998. Un cas de peste de l'écrevisse en France dans le bassin de la Seine. L'Astaciculteur de France, 54, 2-11. 
MATTHEWS M.A., REYNOLDS J.D., KEATINGE M.J., 1993. Macrophyte reduction and benthic community alteration by the crayfish, Austropotamobius pallipes (Lereboullet). Freshwater Crayfish, 9, 289-299.

MCCARTHY D.T., 1977. The effects of drainage on the Tremblestown river, I. Benthic invertebrates and flora. Irish Fisheries Investigations, A16, 1-18.

MORI M., SALVIDIO S., ISOLA G., CRESTA P., 1996. Struttura demografica di quattro popolazioni del gambero d'acqua dolce, Austropotamobius pallipes (Lereboullet), della Liguria (Italia). Ann. Mus. Civ. St. Nat. "Giacomo Doria”, 91, 341-354.

NEVEU A., BACHELIER E., 2002. Mortalité d'Austropotamobius pallipes sur le bassin de la Sèvre Niortaise. Présence de l'aphanomycose. L'Astaciculteur de France, 76, 2-4.

NYSTRÖM P., 2002. Ecology. In: D.M. HOLDICH (Ed.). Biology of freshwater crayfish. Blackwell Science. London. pp. 192-235.

OIDTMANN O., HEITZ D., ROGERS D., HOFFMANN R.W., 2002. Transmission of crayfish plague. Disease of Aquatic Organisms, 52, 159-167.

REYNOLDS J.D., 1988. Crayfish extinctions and crayfish plague in central Ireland. Biological Conservation, 45, 279-285.

ROSECCHI E., POIZAT G., CRIVELLI A., 1997. The introduction of freshwater fish and crayfish species in the Camargue: history, origins and changes in assemblages. Bull. Fr. Pêche Piscic., 344-345, 221-232

SLATER M., ATKINSON M., ROGERS D., 2000. Environment agency response to a crayfish mortality on the River Shep, Cambridgeshire. In: D. ROGERS and J. BRICKLAND (Eds). Crayfish Conference Leeds. Environment Agency. Leeds. pp. 1-8.

SOUTY-GROSSET C., GRANDJEAN F., GOUIN. N., 2004. Conservation and management of native Crayfish populations. Freshwater Crayfish, 14, 1-20.

VIGNEUX E., 1997. Introductions of freshwater decapod crustaceans into France. Can we speak of management? Bull. Fr. Pêche Piscic., 344-345, 357-373.

VIGNEUX E., KEITH P., NOEL P., 1993. Atlas préliminaire des crustacés décapodes d'eau douce en France. Collections Patrimoines Naturels 14, MNHN, Ministère of Environnent, Paris. 55 p. 
